\title{
Device System
}

National Cancer Institute

\section{Source}

National Cancer Institute. Device System. NCI Thesaurus. Code C50311.

A group of independent but interrelated devices working together. 